\title{
ЦІННІСНІ ПАРАМЕТРИ МОВЛЕННСВОЇ ПОВЕДІНКИ ДИТИНИ СТАРШОГО ДОШКІЛЬНОГО ВІКУ
}

\begin{abstract}
Анотація. Мета статті полягає у визначенні змістового наповнення та ролі смислових конструктів й ціннісних орієнтацій, що регулюють мовленнєву поведінку дитини 5-7 років у взаємодії з дорослими та однолітками. Збір даних щодо виявлення особливостей вибору та змісту ціннісних орієнтацій дітей використано серію завдань, які об’єднані експрес-діагностикою сфрери ціннісних орієнтацій дошкільника, бесіду «Чинники вибору дитиною соціально значимих цінностей», методика обстеження рівня комунікативномовленнєвого розвитку. Результати дослідження ціннісної складової в розвитку комунікативно-мовленнєвого розвитку дозволяє на основі аналізу обстеження мовлення та його прояву у поведінці дитини старшого дошкільного віку підтвердити наступні положення. Діяльність особистості в контексті певної сфери реальності визначається станом напрацьованої на даний час системи конструктів щодо неї та відображає досвід, що має дитина та ступінь усвідомлення цього досвіду в поняттях. При цьому системи конструктів можуть бути дуже різними у плані складу, змісту та організащії взаємовідношень. Всі взаємопояснення та доповнення зв’язків полягають у тому, що ощінювання різними конструктами у досвіді даної людини може бути наповнено та пов'язано емощійно значущими для дитини ситуаціями та досвідом спілкування з близькими дорослими, а також з тією змістовно значущою провідною діяльністю, яка сформована у дитини. Вибір рішення дитини про подальшу участь у мовленнєвій ситуації залежить від здатності дитини виділити головний зміст ситуації взаємодії та здатності до вибору основного принципу зміни ситуації. Якщо орієнтовно-дослідницька і виконавська частина комунікативно-мовленнєвої діяльності націлює дитину на постійну увагу до людини як головного змісту будь-якої інфрормації в різних видах предметнопрактичної діяльності, то це сприяє розвиткові комунікативних властивостей особистості. Орієнтація на людину, комунікативна спрямованість у взаємодії визначає швидке і якісне засвоєння мови, необхідного як інструмента сощіального контакту, забезпечує розвиток здібності застосування мови для реальних цілей і задач мовного спілкування.
\end{abstract}

Ключові слова: дитина, цінності, мовленнева поведінка, особистісний розвиток, психосемантика.

Mykhalska Svitlana, Mykhalska Yulia Kamianets-Podilskyi Ivan Ohienko National University

\section{VALUES PARAMETERS OF SENIOR PRESCHOOLER SPEECH BEHAVIOUR}

Summary. The aim of the article consists in determining the content filling and role of the meaning constructs as well as value orientations which regulate speech behaviour of 5-7-year-olds in the interaction with adults and children of the same age. In collecting the data concerning the identification of the children's choice peculiarities and value orientation contents we used the series of tasks united by the express diagnostics of the preschooler value orientation sphere, discussion "Factors of choosing socially significant values by a child", methods of investigating the level of communicative speech development. The results of investigating the value component in the communicative speech development enable on the basis of examining speech and its manifestation in senior preschooler behavior to prove the following statements. Individual activity in the context of the reality particular sphere is determined by the state of the currently developed constructs system concerning this personality and reflects the experience which a child owns as well as the degree of realizing this experience in notions. All mutual explanations and additional links consist in the fact that evaluating with different constructs in the experience of a given person may be filled and connected by the situations and experience of communicating with the close adults emotionally significant for the child as well as by the meaningfully significant leading activity formed in the child. The child's choice about further participation in the speech situation depends on the child's ability to distinguish the gist of the interaction and the ability to choose the main principle of its changing. If the orientation-investigation and execution part of the communication activity aims the child at the permanent attention to a human as the main content of any information in different kinds of subject and practice activity, this facilitates the development of individual communicative characteristics. Orientating on a person, communicative direction of the interaction predetermines quick and high-quality mastering of the language, which is necessary for social contact, provides the development of language application ability for real goals and tasks of linguistic communication.

Keywords: child, values, speech behavior, personal development, psychosemantics.

Постановка проблеми. На сьогодні нагальною е потреба в реалізації системного підходу до вивчення психічної діяльності на основі системоутворювального чинника - френомена антиципації, що е проявом творчості у комунікативній діяльності, зокрема мовленнєвій поведінці в процесі особистісного зростання. Пошук психологічних закономірностей, що пояснюють мовленневу поведінку старшого дошкільни- ка та особливості його особистісного зростання крізь призму антиципації дозволяе виявити специфріку ціннісних орієнтирів, що впливають на ефрективність смислової регуляції мовленневої поведінки дитини в знайомих та невизначених комунікативних ситуаціях, визначення ролі смислових конструктів та ціннісних орієнтацій, що регулюють активність старшого дошкільника у системі взаємодії «людина-людина» у про- 
цесі прийняття значущих рішень про подальшу мовленнєву поведінку. Розуміння мовленнєвої поведінки дитини дошкільного віку потребує реконструкції індивідуальних систем значень, через призму яких суб'єкти відображають себе, довкілля та окремі сфери реальності. Індивідуальні значення розглядаються у фрормах образів, символів, вербальних понять, а також ритуальних та комунікативних дій. Саме в цьому полягає основне завдання психосемантики.

Аналіз останніх досліджень і публікацій. Методологічними підвалинами психосемантичного підходу були більш ранні наукові ідеї про взаємозв'язок мови та свідомості таких класиків психології як Л. Виготський, О. Леонтьев, О. Лурія, Дж. Келлі та Ч. Осгуда [1-4].

З'ясування особливостей значень, які фрункцінують на індивідуальному груповому та суспільному рівні, є не простим завданням, оскільки будучи засобом опису дійсності, самі значення (поняття) можуть не усвідомлюватися як такі. Для їх усвідомлення їх необхідно виразити в системі інших значень. Усвідомлення системи значень суб'єкту, групі або суспільству необхідно для розширення картини світу і власне самої дійсності. Дійсність репрезентована суб’єкту через призму чуттєвої моделі світу у формі перцептивних образів, а також знакових та концептуальних моделей. Для наївного, нередлексуючого суб'єкта дійсність є «злитою» 3 цією моделлю. Рефрлексія понятійних форм, дає можливість через констатацію множинності можливих моделей світу розширити об’ект пізнання і напрацьвані засоби пізнання, переборюючи позищію «наївного реалізму", забезпечити суб’єкту певну свободу у виборі і конструюванні засобів пізнання.

Психосемантика виходить 3 того, що рефлексія засобів пізнання, використовуваних суб'єктом, необхідна не лише в рамках наукового мислення, але й у сорері житейської, буденної свідомості. Слід погодитися з О. Улибіною, що, попри зневажливість відтінку, який міститься в терміні «буденна свідомість", остання заслуговуе уваги науковців не меншою мірою ніж наукова свідомість [6]. Адже буденна свідомість є природним рівнем відображення дійсності, який попри всю його неращіональність та примітивність забезпечують, як правило, необхідний рівень адаптації до повсякденності. Імпліщитна картина світу, що міститься у буденній свідомості, набувае певний самостійний онтологічний статус і впливае, навіть, будучи ілюзорною, на його реальний життевий вибір, прийняття рішень, окремі вчинки та на всю поведінку в цілому. Особливого значення ці позиції набувають у контексті аналізу понять та значень, які демонструють картину світу дитини у модусі її відносин з іншими людьми.

Виділення не вирішених раніше частин загальної проблеми. Поняття, які відображають свідомий та неусвідомлений досвід взаємодії з соціальним оточенням, які надалі регулюють стосунки дитини з дорослими та однолітками повною мірою імпліцитно вказують на очікування дитини стосовно поведінки оточуючих людей та прогнозований варіант особистої поведінки. Якщо ми хочемо осягнути індивідуальні відміни між тими чи іншими суб'єктами, то велику користь у цій справі привносять дослідження відмінностей у їхніх індивідуальних системах значень.
Мета статті. Головною метою ціеї роботи є визначення змісту індивідуальних значень категорій, що характеризують ціннісні орієнтації дитини старшого дошкільного віку та виявлення зв'язку між сформованими цінностями, яку скеровують та регулюють стосунки дитини 3 дорослими та однолітками та рівнем розвиненості мовлення дитини проведено дослідження, в рамках якого проаналізовано означений зв'язок.

Виклад основного матеріалу. У перевірці зв'язків між досягненнями мовленневої поведінки дитини та ціннісними оріентаціями дитини старшого дошкільного віку ми виходили 3 положення про те, що ціннісні оріентації є системо утворюючим психологічним надбанням, котре виступає характеристикою зростаючих можливостей дитини дошкільного віку у свідомому виявленні психологічного простору «Я». В ціннісних орієнтаціях відбивається рівень суб'єктної активності дитини, ступінь дорослішання та гармонізації емоційних, когнітивних, вольових досягнень, що мають прояв в поведінці, відносинах з іншими людьми, в пізнавальній та предметнопрактичних видах діяльності.

Збір даних щодо виявлення особливостей вибору та змісту ціннісних орієнтацій дітей використано серію завдань, які обєєнані експрес-діагностикою сорери ціннісних орієнтацій дошкільника [5].

$\mathrm{У}$ даній методиці дослідження цінностей дитини дослідник виходить з позитивних тверджень. Всі запропоновані дитині для самоідентифрікації цінності $є$ позитивними. Характеризуючи себе у просторі сорормульованих щінностей у такий спосіб, дошкільник не відчуває й тіні загрози почуттю власної гідності, а також виключаеться будь-яка можливість спричинення йому образи чи інших негативних переживань. Малюку не пропонуеться також ранжувати цінності, тобто експліцитно надавати перевагу тим чи іншим з них. Учасник бесіди лише аналізуе кожну із запропонованих цінностей окремо, визначаючи, якою мірою вона підходить для характеристик його цінностей як суб'єкта життєдіяльності у тій чи іншій ситуації. Процедура ієрархізації цінностей є результуючим етапом обробки даних, яка здійснюеться без участі досліджуваного (автоматизовано). За допомогою методики у кожної дитини виокремлюеться по вісім ціннісних характеристик, які формують вершину індивідуальної іерархії цінностей. Після аналізу дитиною запропонованих їі мікроситуацій (запитань) відносно наявності у неї схильності до реалізації тих чи інших позитивних цінностей, нібито висвітлюеться "прихована фрігура», яка дає уявлення про унікальну структуру глибинного змісту індивідуальних переваг конкретної особистості. У кожній з представлених ситуащій, що подані у наочно-образному вигляді (малюнки), учаснику бесіди пропонуеться оцінити найважливіше з його погляду, щось «цінне». В такий спосіб запропоновано 17 ціннісних орієнтацій, які відображають важливий зміст в ситуащіях взаємодії дитини 3 оточенням. Вони характеризують модальності реальної дійсності «людина-людина», «людина-природа", "людина-техніка», «людинамистецтво», а також цінності, що спрямовують увагу дитини на внутрішній світ особистого життя, тобто цінності-інструментарії, що регламентують особисту поведінку. 
Тим самим, враховуючи вікові особливості дітей дошкільного віку для дослідження було відібрано цінності, які відображають досвід ії життя. Зміст провідних ціннісних орієнтацій дітей визначався за двома класами цінностей: цінності-блага та цінності-регламенти. До цінностейблаг належать наступні із запропонованих дітям ціннісних характеристик: «сім'я», «щастя», «здоров'я», «дружба», «краса природи», «краса мистецтва», "краса техніки», «зовнішня краса», «творчість», «гроші». Цінності-регламенти містять у собі: «співпереживання», «самостійність», «допитливість», «цілеспрямованість, «впевненість», «сміливість», «наполегливість».

Також була проведена діагностична бесіда «Чинники вибору дитиною соціально значимих цінностей», що включала наступні блоки:

- Знайомство. Загальна інформація.

- Світоглядні уявлення. Етичні інстанції. Довільна поведінка.

- Етичні інстанції у взаемодії дитини з дорослим та однолітками.

- Мисленнева діяльність.

- Прояви довільної поведінки дитини під час спілкування з дорослим.

- Оцінювання дитиною поведінки інших у відповідності до засвоєних соціально значущих цінностей (мотиваційна складова).

Дітям показувались картинки, проводилась бесіда і спостереження, задавались питання: «Чи знаєш ти правила поведінки, яких треба дотримуватись, перебуваючи в громадських місцях? Пригадай їх», «Чи вважаєш ти необхідним завжди ї дотримуватись?», «У місці, де багато людей можливо загубитися. Якщо так станеться, що ти будеш робити? До кого звернешся за допомогою?», «А у тебе $є$ друзі? Розкажи про них», «Що потрібно робити, щоб дружба була міцною?», «Бувае, що друзі щось не поділили або посварилися. Що робити в такій ситуації?» та інші.

Аналіз комунікативно-мовленнєвого розвитку дошкільника проведено за діагностичним обстеженням методики Т. Піроженко та додатковим обстеженням фонетичних, синтаксичних та семантичних якостей мовлення.

Кількісно-якісний аналіз отриманих експериментальних даних дозволив встановити тенденції і виявити чинники вибору дитиною соціально значимих цінностей. Експериментальну групу склали 133 дітей старшого дошкільного віку.

В результаті статистичного аналізу експериментальних даних отримано факти, що дозволяють інтерпретувати питання про ціннісні параметри мовленнєвої поведінки дитини.

Серед всіх пропонованих для тлумачення, пояснення та інтерпретації дитиною значень, що характеризують ціннісні орієнтації найбільший вибір мають цінності, які характеризують сферу дійсності «людина - людина». I це підтверджуе основну спрямованість активності дитини на іншу людину. Так, у «полі цінностей» серед всіх пропонованих дитині для вибору та трактування цінностей (краса природи, краса мистецтва, впевненість, краса техніки, сміливість, наполегливість, гроші) з високим відсотком вибору серед дітей опинилися: сім'я, щастя, здоров'я, дружба, співпереживання, зовнішня краса людини, творчість (таблиця 1).
Таблиця 1

Вибір соціально значущих цінностей (кількісний та відносний вираз)

\begin{tabular}{|l|c|c|}
\hline $\begin{array}{c}\text { Соціальнозначущі } \\
\text { цінності }\end{array}$ & $\begin{array}{c}\text { Кількість } \\
\text { респондентів } \\
\text { (осіб) }\end{array}$ & $\begin{array}{c}\text { Кількість } \\
\text { респондентів } \\
\text { (\%) }\end{array}$ \\
\hline Сім'я & 89 & $67 \%$ \\
\hline Здоров'я & 81 & $61 \%$ \\
\hline Дружба & 43 & $32 \%$ \\
\hline Щастя & 27 & $20 \%$ \\
\hline Творчість & 25 & $19 \%$ \\
\hline Співпереживання & 20 & $15 \%$ \\
\hline $\begin{array}{l}\text { Зовнішня краса } \\
\text { людини }\end{array}$ & 20 & $15 \%$ \\
\hline
\end{tabular}

Кореляція між вказаними цінностями, що виражені у поняттях та рівнем розвитку мовлення дитини 3 врахуванням шкали оцінок мовленневого розвитку (низький 1-2 бала, високий 4-5, середній - 3 бала дозволяе відзначити, що чим вищі по рангу значущість цінності (сім'я - 67\% дітей вибрали для тлумачення та розповіді; здоров'я $61 \%$; дружба - 32\%) тим більший кореляційний зв'язок підтверджуе, що досвід спілкування, обговорення з близькими людьми вказаних тем та питань надає дитині можливість наповнити індивідуальним значенням вказані поняття, представити у мовленні когнітивну складність та повноту розуміння тієї цінності, яку дитина обрала для пояснення.

Вказана в інтерпретації результатів тенденція про взаємозв'язок рівня мовленнєвого розвитку та значущими для дитини ціннісними оріентаціями підтверджуеться результатами аналізу емпіричних даних щодо актуальних цінностей, якими керуеться дитина та рівнем мисленневого розвитку (вміння аналізувати ситуацію спілкування, розуміти поведінку учасників комунікації, узагальнювати етичні мотиви, причинний характер особистих дій та поведінкових дій оточуючих людей).

Представимо аналіз отриманих даних про ціннісні орієнтації та рівень розвитку мислення дитини. На питання: якій відсоток із загальної вибірки складають діти, що отримали оцінку 4-5 (високий рівень) та оцінку 1-2 (низький рівень) мисленневого розвитку та в яких підтвердженнях вибраних ціннісних оріентацій це проявляється, можна узагальнити, що саме знайомий найближчий досвід дитини, який узагальнено у поняттях найвищого рейтингу («сім'я», «дружба", «краса природи») надає дитині можливість порівнювати, аналізувати, узагальнювати особистий досвід в поняттях.

Важливо зазначити, що значна кількість дітей (високий відсоток із всіх учасників обстеження $-38 \%$ ), демонструють низький рівень мисленневого розвитку. Дані узагальнено зі значень всіх пропонованих для тлумачення та пояснення понять, що характеризують вибране для експериментального обстеження «Поля цінностей». Перелік цінностей, які виражені у поняттях та пропоновані для вибору дитини: сім'я, щастя, здоров'я, дружба, співпереживання, краса природи, краса мистецтва, зовнішня краса людини, самостійність, допитливість, творчість, цілеспрямованість, впевненість, краса техніки, сміли- 
вість, наполегливість, гроші. В результатах обстеження виявлено, що деякі поняття не мають відповідей з боку дитини та не наповнені особистісним змістом. Тільки одна третина дітей зі всіх учасників обстеження (29\%) продемонструвала високий рівень мисленнєвого розвитку з погляду аналізу, порівняння, узагальнення різних по змісту картинок, що розповідають про дійсність «людина-ситуація».

Можливість регулящї особистої поведінки, прояв довільної поведінки дитини під час спілкування 3 дорослим представимо в наступному аналізі. На питання: якій відсоток високих значень (4-5 балів) демонструють діти із загальної кількості учасників обстеження, отримано наступні результати. Дані вказують на те, що поведінка дитини старшого дошкільного віку набирає ознак довільності, але ж потребує допомоги й підтримки з боку дорослого, який через оцінку, підтримку самооцінки, збільшення усвідомленості дитиною понять та значень, що регулюють поведінку через прийняті дитиною норми та цінності про стосунки між людьми, спрямовуе розвиток довільної регуляції поведінки та комунікативної діяльності дошкільника.

Аналіз мисленнєвої діяльності проведено у порівнянні із можливістю оцінювання дитиною поведінки інших у відповідності до засвоєних сощіально-значимих цінностей. Це надало можливість пояснення мотивуючих причин до контактів 3 іншими людьми (мотиващійна складова про вибір мовленневої поведінки та прийняття рішень щодо подальшого контакту - узгодження, роз'єднання, протиріччя тощо). Виявлено якій відсоток високих значень (4-5 балів) та якій відсоток низьких значень (1-2 бали) демонструють діти із загальної кількості учасників обстеження.

Підвищення відсотку (до 53\%) дітей, що показали мисленневі якості в аналізуванні саме поведінкових дій оточуючих людей, вказує на причинно-наслідкові зміни в ситуаціях спілкування та підтверджуе актуальність важливої для дитини реальності - взаємодії 3 іншою людиною. Конкретизація завдання щодо пояснень правил та етичних інстанцій у взаємодії дитини з дорослими та ровесниками вказує на те, що особистий досвід дитини, узагальнений в ціннісних орієнтаціях, виконуе для дитини фрункцію орієнтування, регулювання та стимулювання відносин з оточуючими людьми.
В цілому, аналіз ціннісної складової в розвитку комунікативно-мовленневого розвитку дозволяе на основі аналізу обстеження мовлення та його прояву у поведінці дитини старшого дошкільного віку підтвердити наступні положення. Загальну ощінку мовленневого розвитку дитини, яка проявляється в різних контекстах (мисленнева діяльність, довільна поведінка, мотиваційна складова оцінювання дитиною поведінки інших у відповідності до засвоєних соціально значимих цінностей) ми також перевірили кореляційні зв'язки за цими параметрами (див. таблицю 2).

Висновки і пропозиції. Отже, діяльність особистості в контексті певної сфрери реальності визначається станом напрацьованої на даний час системи конструктів щодо неї та відображає досвід, що має дитина та ступінь усвідомлення цього досвіду в поняттях. При цьому системи конструктів можуть бути дуже різними у плані складу, змісту та організації взаємовідношень. Всі взаємопояснення та доповнення зв'язків полягають у тому, що ощінювання різними конструктами у досвіді даної людини може бути наповнено та пов'язано емощійно значущими для дитини ситуаціями та досвідом спілкування з близькими дорослими, а також з тією змістовно значущою провідною діяльністю, яка сформована у дитини. Вибір рішення дитини про подальшу участь у мовленневій ситуації залежить від здатності дитини виділити головний зміст ситуації взаємодії та здатності до вибору основного принципу зміни ситуащії.

У фороуванні цієї здатності важливу роль відіграє сорормованість інтересу до людини, сама цінність «людина». Виділення головного змісту і принципу зміни ситуації взаємодії залежить, на наш погляд, від орієнтащії дитини на людину як основну змістовну характеристику ситуації спілкування. У системі «людина-ситуація» партнер, учасник комунікащії, є основною і найбільш динамічною частиною цілісного образу ситуації. Спрямованість до людини, установка на відповідну реакцію, розуміння ситуативних значень емоційних станів людини як партнера взаємодії, ціннісні орієнтації і характер очікувань, пов'язаних з людиною, багато в чому визначають функціональні особливості поведінки між учасниками реального контакту.

Якщо орієнтовно-дослідницька і виконавська частина комунікативно-мовленнєвої діяльності націлюе дитину на постійну увагу до людини як

Рівні розвитку контекстів особистісного розвитку та кореляційні зв'язки

Таблиця 2 відповідно до рівнів розвитку мовлення

\begin{tabular}{|c|c|c|c|c|c|c|c|c|}
\hline \multirow[b]{2}{*}{$\begin{array}{c}\text { Контексти } \\
\text { особистісного } \\
\text { розвитку }\end{array}$} & \multicolumn{3}{|c|}{$\begin{array}{c}\text { Рівні розвитку } \\
\text { (значення рівнів } \\
\text { розвитку мовлення) }\end{array}$} & \multirow[b]{2}{*}{$\begin{array}{c}\text { Коефіцієнт } \\
\text { кореляції } \\
\text { за } \\
\text { Пірсоном }\end{array}$} & \multirow[b]{2}{*}{$\underset{\text { зв'язку }}{\text { Напрямок }}$} & \multirow[b]{2}{*}{$\begin{array}{c}\text { Сила } \\
\text { зв'язку }\end{array}$} & \multirow{2}{*}{$\begin{array}{c}\text { Критичне } \\
\text { значення } \\
\text { статистичної } \\
\text { значимості }\end{array}$} & \multirow[b]{2}{*}{ Результат } \\
\hline & 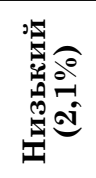 & 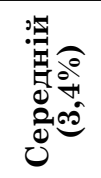 & 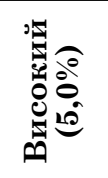 & & & & & \\
\hline $\begin{array}{c}\text { Мисленнева } \\
\text { діяльність }\end{array}$ & $2,8 \%$ & $5,4 \%$ & $9,0 \%$ & 0,999 & позитивний & сильний & $\mathrm{p} \leq 0,05$ & значима \\
\hline $\begin{array}{l}\text { Довільна } \\
\text { поведінка }\end{array}$ & $8,6 \%$ & $14,5 \%$ & $18,3 \%$ & 0,988 & позитивний & сильний & $\mathrm{p} \leq 0,05$ & значима \\
\hline $\begin{array}{l}\text { Мотиваційна } \\
\text { складова }\end{array}$ & $2,9 \%$ & $3,5 \%$ & $4,7 \%$ & 0,983 & позитивний & сильний & $\mathrm{p} \leq 0,05$ & значима \\
\hline
\end{tabular}


головного змісту будь-якої індрормації в різних видах предметно-практичної діяльності, то це сприяе розвиткові комунікативних властивостей особистості. Орієнтація на людину, комунікативна спрямованість у взаємодії визначає швидке i якісне засвоєння мови, необхідного як інструмента соціального контакту, забезпечує розвиток здібності застосування мови для реальних цілей і задач мовного спілкування.

Перспективи подальших досліджень полягають у порівнянні психологічних особливостей мовленневої поведінки дитини старшого дошкільного віку у взаємодії з однолітками в умовах традиційних та інноваційних моделей освіти.

\section{Список літератури:}

1. Выготский Л.С. Мышление и речь. Собрание сочинений : в 6 томах. Т. 2. Москва : Педагогика, 1982.361 с.

2. Келли А. Дж. Теория личностных конструктов. Санкт-Петербург : Речь, 2000. 249 с.

3. Леонтьев А. Н. Деятельность. Сознание. Личность. Москва : Смысл, 2004. 352 с.

4. Лурия А.Р. Об историческом развитии познавательных процессов. Москва : Наука, 1974. 172 с.

5. Піроженко Т.О., Соловйова Л.І., Ладивір С.О., Карабаева I.I., Хартман О.Ю., Федорчук О.І. та ін. Ціннісні оріентації дитини у дорослому світі : навч.-метод. посібник. Київ : Видавничий Дім «Слово», 2016. 248 с.

6. Улыбина Е.В. Психология обыденного сознания. Москва : Смысл, 2001. 266 с.

\section{References:}

1. Vygotskij L.S. (1982) Mishlenie i rech. Sobranie sochinenij [Thinking and speech. Collected works], vol. 2. Moscow: Pedagogika. (in Russian)

2. Kelli A.Dzh. (2000) Teoriia lichnostnykh konstruktov [Theory of personality constructs]. Sankt-Peterburg: Rech. (in Russian)

3. Leontiev A.N. (2004) Deiatelnost. Soznanie. Lichnost [Activity. Consciousness. Personality]. Moscow: Smysl. (in Russian)

4. Luriya A.R. (1974) Ob istoricheskom razvitii poznavatelnykh protsessov [On the historical development of cognitive processes]. Moscow: Nauka. (in Russian)

5. Pirozhenko T.O., Soloviova L.I., Ladyvir S.O., Karabaieva I.I., Hartman O.Yu., Fedorchuk O.I., et al. (2016) Tsinnisni oriientatsii dytyny u doroslomu sviti [The traditional ornate children have grown up]. Kyiv: Vydavnychyi Dim «Slovo». (in Ukrainian)

6. Ulybina E.V. (2001) Psykholohiia obydennogo soznaniia [The psychology of everyday consciousness]. Moscow: Smysl. (in Russian) 